INFORMAATIOTUTKIMUKSEN PÄIVÄT 2020

\title{
Library labit linkkinä digitaalisten kirjastoaineistojen ja tutkimuksen välillä
}

\author{
Liisa Näpärä \\ Kansalliskirjasto, Helsingin yliopisto \\ liisa.napara@helsinki.fi \\ https://orcid.org/0000-0002-6473-5896
}

\section{Library labit tutkijapalveluiden esimerkkinä}

Esityksessä kerrotaan, mikä library lab on ja miten tutkijalähtöisiä datapalveluita kehitetään Kansalliskirjastossa Digitaalinen avoin muisti (DAM) -hankkeessa. Taustalla tutkijapalveluiden kehittämisessä on digitaalisten ihmistieteiden nousu ja tutkijoiden kasvava tarve käyttää tutkimusaineistonaan digitaalista dataa. Lisäksi hankkeen taustalla on Kansalliskirjaston halu kehittää hajallaan olevia tutkijapalveluita nykyistä paremmin tutkimuksen eri vaiheita tukeviksi.

Artikkeli on lisensoitu Creative Commons Nimeä-EiKaupallinen-JaaSamoin 4.o Kansainvälinen -lisenssillä 
Library labit ovat linkkejä kirjastoaineistojen ja tutkijoiden välillä (Mahey ym. 2019, Snickars 2018). Ne sijaitsevat kansalliskirjastojen lisäksi myös yliopistojen kirjastoissa ja hieman laajemmassa merkityksessä labeja voi löytää digitaalisten ihmistieteiden tutkimusyksiköistä. Ihanteellisen mallin mukaan lab on sekä fyysinen että virtuaalinen tila, jossa tutkijat voivat käyttää vuorovaikutteisesti aineistoa sekä jakaa luomiaan tutkimustuotoksia toisille aineistojen käyttäjille. Tuotokset voivat olla perinteisten artikkelien lisäksi digitaalisten ihmistieteiden työkaluja, jotka on tarkoitettu aineiston analysointiin ja visualisointiin tai ne voivat olla uusia tietokantoja, jotka sisältävät uutta tietoa rikastetun datan muodossa.

\section{Aineistonkeruu}

Hankkeessamme toteutettiin vertailuanalyysi (benchmarking), jonka tavoitteena oli selvittää, mitä muiden maiden kansalliskirjastoissa tällä hetkellä tehdään digitaalisten aineistojen käytön edistämiseksi ja millaisia tutkijapalveluita heillä on luotu digitaalisten aineistojen ympärille. Haastattelimme tätä tarkoitusta varten seitsemän eri labin edustajia ja yhteensä haastateltavia oli 12 henkilöä. Haastateltavamme olivat Saksasta, Belgiasta, Ranskasta, Espanjasta, Ruotsista ja Tanskasta, Lisäksi käytimme runsaasti internetissä saatavaa aineistoja, kuten sosiaalista mediaa, artikkeleita ja labien internetsivuja. Tämä muistutti metodiltaan digitaalista etnografiaa tiiviin ja osallistuvan havainnoinnin vuoksi.

Vertaisoppimisella ja -analyysilla selvitetään tavallisesti olemassa olevia parhaita käytäntöjä, minkä jälkeen näitä sovelletaan paikallisesti omiin tarpeisiin ja lähtökohtiin (Carol 2011; Stroobants \& Bouckaert 2014, 211-213). Käytäntöjen soveltaminen on välttämätöntä, koska esimerkiksi tekniset ratkaisut, osaaminen ja resurssit tuovat erilaisia mahdollisuuksia ja rajoituksia toteuttamiseen. Lisäksi organisaatiokulttuuri, ihmiset ja tavoitteet vaihtelevat paikallisesti jonkin verran kansainvälisistä avoimuuden, eettisyyden ja monitieteisyyden arvoista huolimatta.

\section{Toiminta tutkimuksen ja aineistojen välissä}

Labeissa ollut avoimuuden kulttuuri välittyi siinä, miten labien edustajat halusivat jakaa kokemuksiaan ja meidän kehityshankkeemme otettiin avoimesti vastaan. Labit muodostavat yhtäältä melko tiiviin mutta samalla melko löyhän yhteisön, joka pitää yhteyttä toisiinsa eri tarkoituksissa. Vain harvat 
henkilöt ovat täysipäiväisesti labin palveluksessa ja suurin osa sijoittuu kirjasto-organisaatiossa muihin tehtäviin tai toimii yliopistolla tutkijana. Linkitys tutkijoiden ja digitaalisten kirjastoaineistojen välillä on olennainen, kun labin toiminnan tarkoituksena on ymmärtää sekä digitaalisten aineistojen ominaisuuksia, tekijänoikeuksia että tutkijoiden tarpeita niiden käyttäjinä.

DAM-hanke kiinnittää huomiota tutkijoiden tarpeisiin ja kehittää niiden mukaisia palveluita. Hanke jatkuu vuoden 2021 syyskuun loppuun asti. Sitä rahoittaa Euroopan aluekehitysrahasto Vipuvoimaa EU:Ita 2014-2020.

\section{Lähteet}

Mahey, M., Al-Abdulla, A., Ames, S., Bray, P., Candela, G., Chambers, S., ... with forewords by ... Papaioannou, G. (2019). Open a GLAMLab. Digital Cultural Heritage Innovation Labs, Book Sprint, Doha, Qatar, 23-27 September, 2019. https://glamlabs. pubpub.org/

Simon, C. (2011). An examination of best practices and benchmarking in corporate libraries. Journal of Management Development, 30(1), 134-141. https://doi.org/10.1108/ 02621711111098433

Snickars, P. (2018). Datalabb på KB. http://www.kb.se/dokument/Bibliotek/utredn_rapporter/ 2018/1.2.1-2017-752.pdf

Stroobants, J. \& Bouckaert, G. (2014). Benchmarking local public libraries using non-parametric frontier methods: A case study of Flanders. Library \& Information Science Research, 36(3-4), 221-224. https://doi.org/10.1016/j.lisr.2014.06.002 